\title{
THE EFFECT OF SPEAKING SELF-EFFICACY AND GENDER IN SPEAKING ACTIVITIES
}

\author{
Hanna Sundari \\ Dasmo \\ Indraprasta PGRI University \\ Address: Jl. Nangka No.58 Tanjung Barat Jakarta Selatan \\ E-mail: hanna.sundari@gmail.com
}

\begin{abstract}
The present study tries to find out the effect of speaking self-efficacy and gender in speaking activities particularly in English as second/foreign language situation, using questionnaire from Bandura's Guide for constructing self-efficacy scales. The Samples of this study were 23 male and 27 female college-students from speaking classes. ANOVA and T-test helped by SPSS 15.0 for windows were employed to investigate speaking self-efficacy, gender and speaking activities. The result showed that the level of speaking self-efficacy both male and female students is moderate. They can moderately perform speaking activities but they think them quite though and difficult. Besides, Sig. for gender scores lower than $.05(.013<$ .05), gender gave significant effect towards speaking activities. Yet, not only speaking self-efficacy partially (Sig .162> .05) but also its simultaneous interaction with gender (Sig .0677 > .05) did not affect significantly towards speaking activities.
\end{abstract}

Keywords: speaking self-efficacy, gender, speaking activities

\begin{abstract}
Abstrak
Penelitian ini mengkaji pengaruh speaking self-efficacy dan gender terhadap kegiatan berbicara khususnya pada situasi Bahasa Inggris sebagai bahasa kedua/asing, dengan menggunakan kuesioner dari Skala Bandura. Sampel diambil dari 23 mahasiswa dan 27 mahasiswi kelas Speaking. ANOVA dan T-test dengan bantuan SPSS 15.0 for windows juga digunakan untuk menghitung speaking selfefficacy, gender dan kegiatan berbicara. Hasil penelitian menunjukkan bahwa level speaking self-efficacy para mahasiswa/i dalam kategori sedang. Mahasiswa/i dapat menampilkan kegiatan-kegiatan berbicara meskipun mereka anggap agak sulit. Selain itu, dengan nilai sig. lebih rendah dari 0,05 (0,013 < 0,05), maka gender berpengaruh signifikan pada kegiatan berbicara. Namun ternyata, speaking self-efficacy baik sendiri (nilai sig. 0,162 >0,05) maupun bersama-sama dengan gender (nilai sig. 0,067>0,05) tidak berpengaruh signifikan terhadap kegiatan berbicara.
\end{abstract}

Kata-kata kunci: efikasi diri dalam berbicara, gender, kegiatan berbicara 


\section{INTRODUCTION}

Teaching English as a second/foreign language in Indonesia now focuses on the concept of communicative competence either orally or written. Finnochiaro and Brumfit (in Richard and Rogers, 2001: 156) wrote that communicative competence's goal is the ability to use the linguistic system effectively and appropriately. It means learners learn English through using it to communicate both pair and group work. They also practice dialogue and comprehensible pronunciation to produce language fluently and acceptably. Yet, fluency and acceptable language is one of purposes in speaking activities and class, too. Speaking (Spratt et al, 2011: 49) involves making use of all the features of connected speech to convey messages completed by intonation, stress, gesture, facial movement, and body language.

Speaking, as one of productive skills, is a complex activity. Accuracy of grammar, use of vocabulary and clear pronunciation are some aspects of speaking for a learner to be considered in speaking class. Moreover, Shumin (in Richards and Renandya, 2002: 204) said speaking a language is especially difficult for foreign language learner because effective oral communication requires the ability to use the language appropriately in social interaction. As a result, adult EFL learners, with lack of exposure to the target language, are relatively poor at spoken English. Shumin (2002: 205) also proposed some factors affecting adult EFL learners' oral communication: age or maturational constraints, aural medium, sociocultural factors, and affective factors.

To be exact, the affective side gives the learners great effect in language learning process. The affective sides here are such as motivation, anxiety, personality traits, attitude, self-esteem, and self-efficacy, and other individual differences, such as gender, age, and
nationality.Sometimes, EFL learners feel extremely anxious to speak English in public; so they are tongue-tied or lost for words. Consequently, their speaking performances end up poorly. In other words, the person's belief concerning his or her completion of task, also called selfefficacy, may influence performing the task. At last, this study aimed to figure out the effect of self-efficacy in speaking class dealt with stable individual difference or gender.

The concept of self-efficacy firstly is theory of Social CognitivebyBandura. Bandura published his seminar work "Selfefficacy: Toward a unifying Theory of Behavioral Change" on 1977. He wrote that self-efficacy proved to be an accurate predictor of performance in the en-active mode of treatment although subjects engaged in no overt behavior (1977:211).Bandura further proposed that a person's attitude, abilities, and cognitive skills comprise what is known as the selfesteem, too(Tilfarlioglu \& Cinkara, 2009). Then a large number of studies in education have been done to observe its implication particularly in second/foreign language learning where affective factors may influence its process and the performance.

As the matter of that, self-efficacy, known also as learner belief, is a term used to refer to a person's belief concerning his or her completion of a task and perceived competency level with performing the task. According to Bandura, self-efficacy beliefs serve as a key motivational force in cognitive system and considered to be a central mediator of effort (Tilfarlioglu \& Cinkara, 2009). In addition, Tilfarlioglu and Cinkara(2009:130)revealed that it mediates the relationship between knowledge and action. In short, a student having knowledge and skill needed in language learning does not always succeed proficiently to perform it.It is because selfefficacy affects individual's behavior in four ways: selecting choice of behavior, 
determining how much and how long of the effort, affecting an individual's thought patterns and emotional reaction, and recognizing human as producers than foreteller. For example, student with low self-efficacy creates fear and doubt that bring him away to pursuit the goals of learning; then he thinks that activities are tougher and more difficult than they really are; this emerges stress and failure on learning. In Rahimi andAbedini (2009: 16), based on what Bernhard and Pajares wrote, self-efficacy refers to learner's belief about their abilities to accomplish a task; it is also the students' judgment of their academic competence. Furthermore, Ehram(in Rahimiand Abedini: 2009) noted that it is a degree to which the student thinks he or she has the capacity to cope with the language challenge. In short, selfefficacy can be defineda personal judgment of one' ability to organize, execute, and cope with academic competence and its challenge.

Moreover, self-efficacy can affect motivation and choice of activities. Student with high self-efficacy will give great effort when facing difficulties, he probably say "I can do this." In contrast, student who has low self-efficacy may doubt his ability, he thinks "It seems hard and difficult." Besides, it also mostly concerns to answer the question: Can I do this task with this situation? (Cubukcu: 2008).Zimmerman (2000: 82-90) wrote that self-efficacy beliefs are not a single disposition but rather are multidimensional in form and differ on the basis of the domain of functioning. For example, one is efficacious on a history test; whereas, the efficacy belief differs on biology test. On the other words, perceived selfefficacy is in a particular task at specific given situation.

Bandura gave domain of where people acquire information about their self-efficacy from. They are from performance accomplishment, vicarious (observational) experiences, social persuasion, and inferences from physiological states (Schunk: 1985).Repeated successes raise selfefficacy; on the other hand, failures get it down.Meanwhile, Zimmerman (2000: 8291) added that self-efficacy focuses on performance capabilities than personal qualities, such as physical or psychological characteristics. To support what Bandura initiated, Cubuksu (2008) summarizes that self-efficacy beliefs are affected more by one's own direct experiences with tasks than social comparison. In self-efficacy, students do not compare their perceived competence with their peer's ability in the same area. They assess themselves of how capable they are to accomplish a given task.

In academic self-efficacy, the studies concentrate more on students' judgments of their capability (Cubukcu: 2008). Cubukcu (2008: 150) wrote that self-efficacy is related to student engagement and leaning. The components of engagement are behavior, cognitive, and motivation. On behavioral engagement, the teacher can observe easily whether the students are engaged of effort, persistence, and help seeking. If they are not efficacious on themselves, they are more likely to give up. In contrast, teacher can't access students' cognitive engagement because it is in their heads. Students with high efficacy use more cognitive strategies than the others when they are engaged with the material deeper. Motivational engagement contains personal interest (like and dislike), value (importance and utility) and affect (Cubukcu: 2008). It can be summarizes that self-efficacy can direct the students to more engagement in academic situation, so that it results in better learning achievement.Cubukcu (2008) wrote the more the students are engaged, the more they learn and the better they perform. 


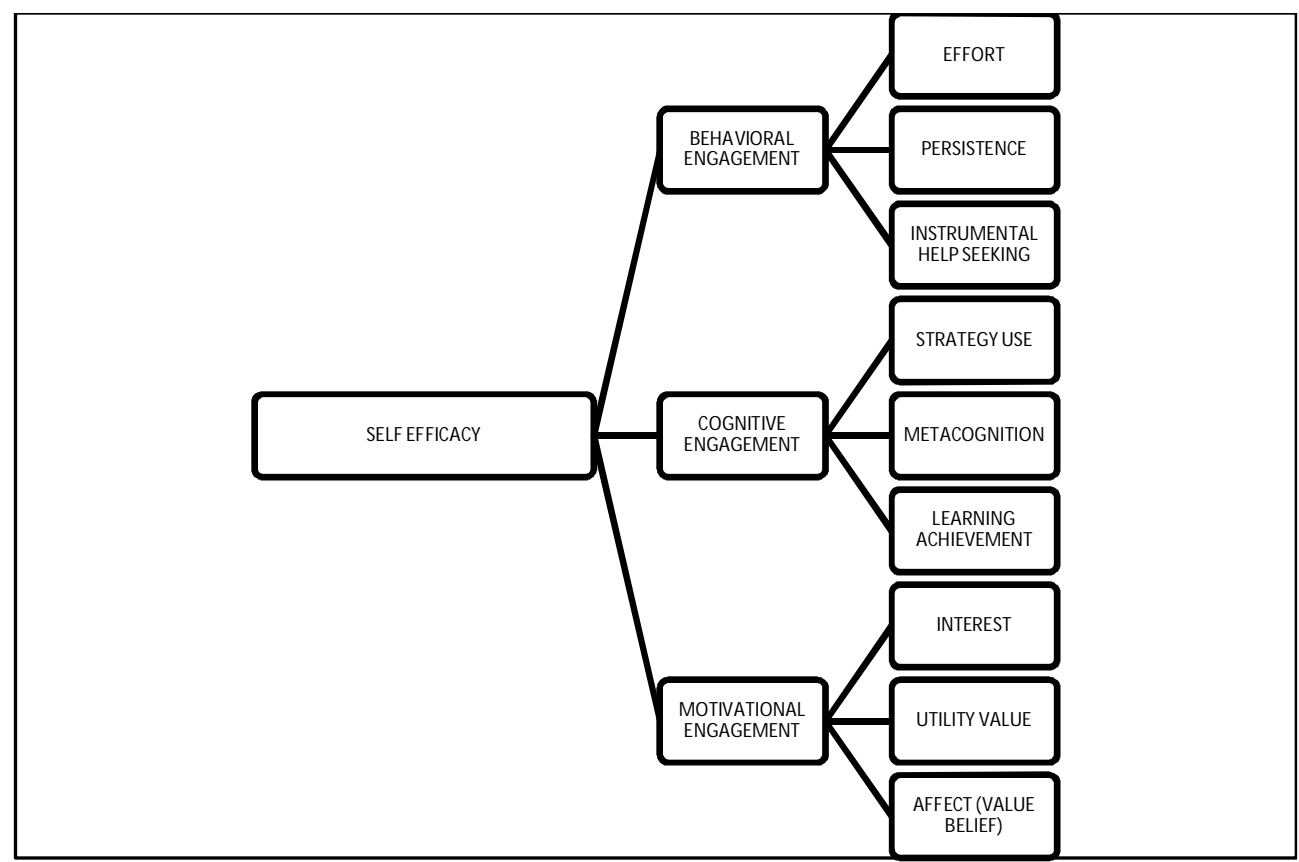

Figure 1A. General Framework for Self-Efficacy, Engagement, and Learning

(Linnebrick \& Pintrich, 2003)

Numerous studies related to selfefficacy and language learning had been done for years. Here in 2009 by Tilfarlioglu and Cinkara, English language learning self-efficacy expectations of 175 students at GUSFL had been carried to investigate levels and relationship with their EFL success. The result showed that the students' level of self-efficacy is relatively high and the cyclical relationship between self-efficacy and achievement. It also confirmed a strong link between them (Tilfarlioglu \& Cinkara, 2009, pp. 135136). Concerning listening comprehension and listening proficiency, Rahimi and Abedini (2009: 19:21) have also conducted research of interface between this skill and EFL learners' self-efficacy. In this case, sixty one undergraduate EFL learners as samples, it showed that there was a direct and significant correlation between selfefficacy and listening comprehension; the findings found that high self-efficacy affected listening test performance significantly and positively. In American classrooms and a Chinese community, a single case study by Wang (2007: 23-24) noted the connection between behavior and self-efficacy belief to perform related task. Moreover, Wang also observed some factors that influenced the development of self-efficacy belief: (1) expertise in the content area, (2) self-perception of English proficiency, (3) task difficulty level, (4) past experience, (5) social persuasion, (6) interest, (7) attitude toward the English language and (8) English speaking community and social cultural context.

In the writing and reading skills, there have also been many researches related to self-efficacy. Study by Shah et al (2011: 8-11) proved that 120 secondary students of Negeri Sembilan Malaysia gained moderate on their self-efficacy levels. Besides, the finding showed a large, significant positive correlation between self-efficacy and writing performance in English. As a result, this means students having high self-efficacy would indeed write well, for they were able to negotiate rules and mechanism while maintaining accuracy of language; meanwhile students 
who believed they to be poor writers would also perform accordingly (Shah, et al. 2011: 10).Sani and Zain (2011: 243254), in addition, investigated the relationship among second language affective factors upon reading ability. There were reading attitudes, self-efficacy, and stable individual difference or gender. The result has shown that boys displayed higher level of L2 reading self-efficacy, though not significant, among the 20016 year old Malay students; moreover, significant positive correlation were found among reading self-efficacy, attitudes and ability (Sani \& Zain, 2011, p. 251). It can be drawn a conclusion that, significant or not, there was any correlation between self-efficacy and language skills in language learning process particularly in EFL situation.

Despite of paucity in studies on the correlation between language learner belief or self-efficacy and stable individual differences such as gender and nationality, some of them, in fact, showed that the male's assessments, belief, and selfbeliefin learning a foreign language are quite different from female. To be exact, Gender itself differs in definitions from the term of sex. Sex is a biological term for being male and female depending on the sex organs and genes (Eksi: 2009). On the other hand, gender, based on Eksi (2009), is socially constructed and culture-bound. Accordingly, people in different culture establish different meaning of gender. Study by Broverman in 1972 found that 41 traits differentiated between women and men. The value items of men are such as aggressive, dominant, competitive, and not very emotional. In contrast, gentle, tactful, and aware of feelings were female-valued traits (Eksi, 2009:38). In fact, the research findings also found that gender do not only attribute on personality traits but also the other three areas: female and male roles, occupations, and physical characteristics.

In the quite different point of view, gender difference itself is the term used to describe socially constructed categories based on sex (Coates, 2007: 63). Coates (2007: 66) also added that gender identity is seen as a social construct rather than a "given" social category; the speaker should be seen as "doing gender" rather than "being". Associated with male and female social categories, Coates (2007:67) proposed that male and female speakers differ in many ways, but there are also many areas of overlap.

There have been few researches observing the differences between male and female learners related to second language learning. The study by Rieger (2009: 29-42) showed that both gender and the target language effect secondary language learners in Hungarian. Male and female learners differed in the perceived importance of practicing the target language with authentic written texts. Moreover, Bernat and Llyod (2007: 79-91) observed that overall males and females held similar belief about language learning. On the other hand, the previous researches by Siebert in 2003 and Bacon and Finnemann in 1992 (in Bernat and Llyod, 2007: 80) found that both male and female is significantly different in belief, motivation, strategy use, and assessment. Study by Zeynali (2012) also supported that male and females differ in the language learning strategies. It showed that both female and male use all three categories of the strategies (Cognitive, metacognitive, and social/affective), however, female learners tend to use social/affective strategy more than male learners do.

Related to speaking, Richards (2008: 19) wrote that oral skills have hardly been neglected in EFL/ESL courses. Based on Brown and Yule's framework of functions of speaking, Richards (2008: 21-28) expanded it into three-part version of talks: interaction, transaction, and performance. Each of speech activities has different in form and 
function and requires different teaching approaches.

First of all, talk as interaction refers to "conversation" and focuses on speakers and how they wish to present themselves to each other than on the message. Interactional spoken English, according to Liao (2009), does not focus on the accuracy and clarity of the information; then, facts/views are not questioned or challenged. By shifting of topics and short turns, interactional conversation is oriented on listener - "listener-oriented." The kinds of talk as interaction are chatting, smalltalk, joking, opening and closing conversations.

Furthermore, talk as transaction refers to situations where the focus is on what is said and done (Richards: 2008). It is message-oriented and the topic is clear. Besides, clarity and accuracy are the central focus. As a consequence, effective and meaningful transfer of information is the most important part than the participants and the interaction, such as class discussion, problem solving activities, and making a telephone call.

Then talk as performance, according to Richards (2008: 27), refers to public talk that transmits information before an audience such as presentation, public announcements, and speeches. This kind of talk is characterized by its generic structure and predictable organization and sequencing. Performance focuses on both listener/audience and message. Moreover, form and accuracy at the same time are considered important.

In addition, some factors affecting adult learners' oral communication, Shumin (2002: 205-206) proposed four of them. They are age or maturational constraints, aural medium, sociocultural factors, and affective factors. The latter factor mentioned related to L2 or foreign language learning is emotions, self-esteem, empathy, anxiety, attitude and motivation.
This study aimed to observe the interactioneffects between speaking selfefficacy and gender in second/foreign language situation particularly for adult learners' speaking activities. Specifically, the research questions are formulated as follow: (1) is there any significant effect between speaking self-efficacy and speaking activity? (2) Is there any significant effect between gender and speaking activities, and (3) is there any interaction between speaking self-efficacy and speaking activities for both male and female college-students?

\section{METHOD}

The purpose of the research was to figure out the interaction and its effect between speaking self-efficacy and gender in speaking activities. A 10-item speaking self-efficacy is adapted from Bandura's Guide for constructing self-efficacy scales (2006: 307-337). The items loaded two dimensions of speaking: ability and activity. The first 6 items containedfluency, accuracy, and pronunciation. Besides, the rest 4 items required some activities in speaking class, such as making dialogue or small talk, giving speech, and conducting debate. On the questionnaire sheet, the participants were asked for rating degree of confidence by recording a number from 0 to 100 ; higher number means higher confidence.

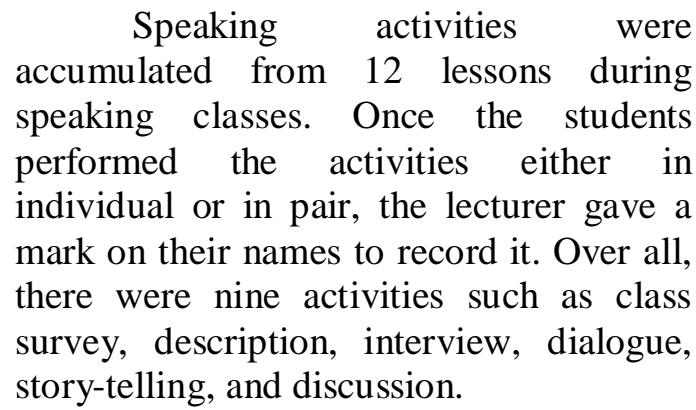

The population of the study was 136 second semester of college-students from four Speaking 2 classes academic year 2012/2013. In addition, these classes were dominated by female with an average 
ratio of 1-to-4. Using purposive random sampling, it was taken 23 male and 27 female college-students as samples.After that, the data obtained was analyzed statistically using ANOVA helped by SPSS 15.0 for windows to answer the alternative hypotheses $\left(\mathrm{H}_{\mathrm{a}}\right)$ below:

1. There is any significant effect between speaking self-efficacy and speaking activities.
2. There is any significant effect between gender and speaking activities.

3. There is any effect of interaction between speaking self-efficacy and gender in speaking activities.

Furthermore, speaking self-efficacy was divided descriptively into three categories: high, moderate and low. The design of study is displayed below:

Table 1. Research Design

\begin{tabular}{|c|c|c|}
\hline \multirow{2}{*}{ Speaking Self-Efficacy } & \multicolumn{2}{|c|}{ Gender } \\
\cline { 2 - 3 } & Male (A1) & Female (A2) \\
\hline High (B1) & A1B1 & A2B1 \\
\hline Low (B2) & A1B2 & A2B2 \\
\hline
\end{tabular}

\section{RESULTS AND DISCUSSION}

This study aimed to figure out the interaction and its effect between speaking self-efficacy and gender in second/foreign language learning situation particularly for adult learners in speaking activities. The average level of speaking self-efficacy descriptively showed male 50.435 and 51.73 for female. It indicates that for both male and female speaking self-efficacy are moderate in speaking class. It means they can moderately perform all activities in speaking classes. Likewise, they believe themselves they can moderately do speaking activities such as class survey, description, interview, dialogue, storytelling, and discussion. By contrast, these moderate values also show that either male or female still feel fear and doubt to perform them in the front of the class. Perhaps they think the activities quite tough and difficult to do. Similarly, the research result in writing, the student with high self-efficacy would write well; on the other hand, low self-efficacy student would write accordingly (Shah, et al. 2011). The moderate self-efficacy levels gained by the students also indicate that they judge themselves neither can nor can't in accomplishing speaking tasks during speaking classroom (Cubukcu, 2008; Rahimi and Abedini, 2009).

Then having been calculated the averages of speaking activities either male or female college-students, the result can be seen on the table below. 
Table 2. Descriptive Statistics of Self-Efficacy and Gender

\begin{tabular}{|c|l|l|l|}
\hline \multirow{2}{*}{ Self-Efficacy (B) } & \multicolumn{3}{|c|}{ Gender (A) } \\
\cline { 2 - 4 } & Male (A1) & Female (A2) & Amount \\
\hline \multirow{3}{*}{ High (B1) } & $\mathrm{n}=10$ & $\mathrm{n}=10$ & $\mathrm{n}=20$ \\
\cline { 2 - 4 } & $\bar{X}=2,90$ & $\bar{X}=4,70$ & $\bar{X}=3,80$ \\
\hline & $\mathrm{s}=2,02$ & $\mathrm{~s}=2,16$ & $\mathrm{~s}=2,24$ \\
\hline \multirow{3}{*}{ Low (B2) } & $\mathrm{n}=10$ & $\mathrm{n}=10$ & $\mathrm{n}=20$ \\
\cline { 2 - 4 } & $\bar{X}=2,30$ & $\bar{X}=3,60$ & $\bar{X}=2,95$ \\
\cline { 2 - 4 } & $\mathrm{s}=1,64$ & $\mathrm{~s}=1,65$ & $\mathrm{~s}=1,73$ \\
\hline \multirow{3}{*}{ Amount } & $\mathrm{n}=20$ & $\mathrm{n}=20$ & $\mathrm{n}=40$ \\
\cline { 2 - 4 } & $\bar{X}=2,60$ & $\bar{X}=4,15$ & $\bar{X}=3,375$ \\
\cline { 2 - 4 } & $\mathrm{s}=1,82$ & $\mathrm{~s}=1,95$ & $\mathrm{~s}=1,985$ \\
\hline
\end{tabular}

From table 2, it demonstrates some findings on level of speaking self-efficacy both male and female college-students related to gender and speaking activities. At first, the mean of speaking activities for female college-students (4.15) scores higher than male does (2.60). The Mean scores indicate, based on gender, significant difference between male and female in speaking activities. Female speakers tend to be more active and perform many activities than male ones in speaking activities.This result gives a proof that male and female speakers differ in many ways (Coates, 2007: 67). Female speakers probably respond differently from male in class activities which are kinds of controlled speaking practices. Controlled speaking practices may more motivate female speakers to perform in front of the class; particularly in class where is dominated also by female students. In the line with researches by Siebert in 2003 and Bacon and Finnemann in 1992 (in Bernat and Llyod, 2007: 80), it found that both male and female is significantly different in belief, motivation, strategy use, and assessment.

The second result, on table 2, shows the mean score of speaking activities from college-students with high self-efficacy (3.80) gains also higher than the mean from low self-efficacy does
(2.95). On the other words, the selfefficacy level effects speaking activity in speaking class.Moreover, level of selfefficacy, in fact, gives different performance in speaking activities. College-students with high self-efficacy perform more activities in speaking class. In the other words, the higher self-efficacy level the students have, the more they perform speaking activities in the class. It means college-students with high selfefficacy try to participate actively in each activity. It can be assumed that for collegestudents with high self-efficacy, it is as a motivational force and a central mediator of effort to practice and be more active in speaking activities (Tilfarlioglu and Cinkara, 2009). Besides, self-efficacy can direct the students to more engagement in academic situation, so that it results in better learning achievement (Cubukcu: 2008).

Before test of hypotheses, it should be tested the data requirement including normality and homogeneity. Then, Kolmogorov-Smirnovtest is carried out to test normality. Sig. scores more than 0.05 which means taken sample from population is called normal.Meanwhile, to test of homogeneity, it is used Levene's test $(\alpha=5 \%)$ to determine the variance. The result is shown on the tables below. 
Tabel 3. The Result of Normality Test

\begin{tabular}{|c|c|c|c|c|}
\hline No. & Groups & Sig. & A & Criteria \\
\hline 1 & A1 & 0,244 & 0,05 & Normal \\
\hline 2 & A2 & 0,532 & 0,05 & Normal \\
\hline 3 & B1 & 0,832 & 0,05 & Normal \\
\hline 4 & B2 & 0,697 & 0,05 & Normal \\
\hline 5 & A1B1 & 0,901 & 0,05 & Normal \\
\hline 6 & A1B2 & 0,447 & 0,05 & Normal \\
\hline 7 & A2B1 & 0,925 & 0,05 & Normal \\
\hline 8 & A2B2 & 0,799 & 0,05 & Normal \\
\hline
\end{tabular}

Tabel 4. The Result of Homogeniety Test

\begin{tabular}{|c|c|c|c|}
\hline \multicolumn{4}{|c|}{$\begin{array}{l}\text { Levene's Test of Equality of Error Variances } \\
\text { Dependent Variable: Speaking Activities }\end{array}$} \\
\hline$F$ & $\mathrm{df1}$ & $\mathrm{df} 2$ & Sig. \\
\hline .442 & 3 & 36 & .725 \\
\hline \multicolumn{4}{|c|}{$\begin{array}{l}\text { Tests the null hypothesis that the error variance of } \\
\text { the dependent variable is equal across groups. } \\
\text { a. Design: Intercept+GN+SE+GN * SE }\end{array}$} \\
\hline
\end{tabular}

Table 3 reveals that all groups get Sig. score more than 0.05 . Consequently, the population where samples are taken distributes normal. While on table 4, Levense's test scores .725 for Sig. which is more than .05; it indicates that variant sample in population is homogeneous. From the results above, it can be drawn a conclusion that samples are normal and homogeneous.

Then usingSPSS 15.0 for window, it calculated testing of hypotheses by twoway ANOVA and T-test for measuring the simple effect in each group related to selfefficacy and gender. As a result, the calculation is displayed on the table below.

Table 5. The Calculation of two-way ANOVA

Tests of Between-Subjects Effects

Dependent Variable: Speaking Activities
\begin{tabular}{|l|r|r|r|r|r|}
\hline Source & $\begin{array}{c}\text { Type III Sum } \\
\text { of Squares }\end{array}$ & df & Mean Square & \multicolumn{1}{c|}{ F } & \multicolumn{1}{c|}{ Sig. } \\
\hline Corrected Model & $31.875^{\mathrm{a}}$ & 3 & 10.625 & 3.000 & .043 \\
Intercept & 455.625 & 1 & 455.625 & 128.647 & .000 \\
GN & 24.025 & 1 & 24.025 & 6.784 & .013 \\
SE & 7.225 & 1 & 7.225 & 2.040 & .162 \\
GN * SE & .625 & 1 & .625 & .176 & .677 \\
Error & 127.500 & 36 & 3.542 & & \\
Total & 615.000 & 40 & & & \\
Corrected Total & 159.375 & 39 & & & \\
\hline
\end{tabular}

a. R Squared $=.200$ (Adjusted R Squared $=.133$ ) 
bahasa \& sastra, Vol. 14, No.2, Oktober 2014 


\section{Hypothesis one: There is any significant effect between speaking self-efficacy and speaking activities.}

It can be seen on table 5 line 4, Sig. scores for self-efficacy .162. It reveals that Sig score is more than $.05(.162>.05)$. Therefore, $\mathrm{H}_{0}$ is accepted and $\mathrm{H}_{1}$ is rejected. In other words, there is no significant effect between speaking selfefficacy and speaking activities.It indicates that the differences of means between high self-efficacy and low one are not significant. Even though college-students with higher self-efficacy also perform higher in speaking activities, in fact, the differences between high and low selfefficacy are not quite significant in speaking activities. The level of selfefficacy either low or high, surprisingly does not give significant effect in speaking activities though students with high selfefficacy participate themselves in more speaking activities. This indicates that high self-efficacy does not automatically emerge and initiate students to participate actively in speaking activity in front of the class. This is contrary to research by Shah et al (2011: 8-11) which showed a large significant positive correlation between self-efficacy and writing performance of secondary students in Malaysia; in speaking activities for college students in Indonesia, speaking self-efficacy does not affect students' speaking activities in speaking class.

\section{Hypothesis two: There is any significant effect between gender and speaking activities.}

From table 5 line 3 , it can be seen that sig. for gender scores .013 where it is lower than $.05(.013<.05)$. As a result, $\mathrm{H}_{0}$ is rejected and $\mathrm{H}_{1}$ is accepted. This indicates that the effects of mean of gender (female and male) are significant. To sum up, stable difference or gender effects significantly in speaking activities where female speaker performs higher than male one. The result is probably consistent with the study by Zeynali (2012). In the research, it is found that female and male significantly differ in language learning strategies where female leaner tend to use social/affective strategy than male learners do.

\section{Hypothesis three:There is any effect of interaction between speaking self- efficacy and gender in speaking activities.}

Based on table 5 line 5 above, it can be seen that sig. for interaction $(\mathrm{GN} * \mathrm{SE})$ between gender and self-efficacy scores .677. The score of sig is higher than $.05(.0677>.05)$, so that $\mathrm{H}_{0}$ is accepted and $\mathrm{H}_{1}$ is rejected. It indicates that there the effect of interaction between gender and self-efficacy toward speaking activities is not significant. Consequently, related to college student selfefficacy,there is no effect of interaction between gender and speaking activities in speaking class.Perhaps, it is not found the relevant research regarding with speaking self-efficacy and gender. However, Zimmerman (2000: 83) wrote that selfefficacy measures focus on performance capabilities to fulfill specific task given, not personality and feeling in general. The tasks here are speaking performances. Moreover, Cubukcu (2008) also believed that self-efficacy related to student engagement and learning achievement in the three areas: behavior, cognitive, and motivation. Besides, self-efficacy deals with cognitively perceived capability of the self, not social. Students do not compare their perceived competence with peers 'abilities (Cubukcu, 2008: 149-150).

\section{CONCLUSION}

In conclusion, speaking selfefficacy for college-students both male and female is moderate; it indicates that they can perform speaking activities in the class though they still feel fear and doubt. Moreover, female speakers are significantly more active and perform 
more speaking activities than male ones. Besides, gender gives significant effect toward speaking activities. Moreover, students with high speaking self-efficacy perform more activities than the low ones. Yet, there is no, in fact significant effect between speaking self-efficacy and speaking activities. At least, there is no simultaneously effect of interaction between speaking self-efficacy and gender toward speaking activities in speaking class.

Based on the research findings, it is suggested that teachers/lecturer should engage all students in the classroom especially in mixed-classes where is dominated by one gender difference. For further research, it can explore more about speaking self- efficacy on specific kind of talk. Besides, it can also investigate selfefficacy on other language skills.

\section{ACKNOWLEDGEMENTS}

We would to send our gratitude to the Dean of the Faculty of Language and Fine Art as well as the Head of English Education Program, Drs. SupenoHadi, M.Hum for his remarkable help and support on the research. Moreover, the authors would like to thank to the Rector of Indraprasta University, Prof. Dr. Sumaryoto for his permission to conduct the research.

\section{REFERENCES}

Bandura, A. (1977). Self-Efficacy:

Towards a unifying theory of

Behavioral Change. Psychological

Review, Vol. 84 No. 2 pp. 191-215.

Bandura, A. (2006). Guide for

Constructing Self-Efficacy Scales.

In -, Self Efficacy Beliefs of

Adolescents (pp. 307-337). -:

Information Age Publishing.
Bernat, E., \& Llyod, R. (2007). Exploring the Gender Effect on EFL

Learners' Belief about Language

Learning. Australian Journal of

Educational \& Developmental

Psychology, Vol. 7; pp 79-91.

Coates, J. (2007). Gender. In C. Llamas, L. Mullany, \& P. Stockwell, The

Routledge Companion to

Sociolinguistics (pp. 62-68). New

York: Routledge.

Cubukcu, F. (2008). A Study of the Correlation between Self Efficacy and Foreign Language Learning Enxiety. Journal of Theory and Practice in Education, 4 (1): 148158.

Eksi, G. (2009). Gender Stereotypes and Gender Roles in the Students Written Work. Journal of Language and Linguistics Studies, April, Vol. 5 No. 1 pp. 37-54.

Liao, G. (2009). Improvement of Speaking Ability through Interrelated Skills. English Language Teaching, Sept, Vol.2, No. 3 (11-14).

Rahimi, A., \& Abedini, A. (2009). The Interface between EFL Learners' Self-Efficacy concerning Listening Comprehension and Listening Proficiency. Novitas Royal, Vol: 3(1), 14-28.

Richards, J. C. (2008). Teaching Listening and Speaking: from Theory to Practice. New York: Cambridge University Press.

Richards, J. C., \& Renandya, W. A. (2002). Methodology in Language Teaching: An Anthology of Current 
Practice. New York: Cambridge University Press.

Richards, J. C., \& Rodgers, T. S. (2001). Approaches and Methods in Language Teaching. Cambridge: Cambridge University press.

Rieger, B. (2009). Exploring Gender and Target Language Effect on Hungarian EFL Learners' Belief about Language Learning. In J. Horvath, M. Nikolov, \& R. Lugossy, UPRT 2008: Emppirical Studies in English Applied Linguistics (pp. 29-42). Pecs: Lingua Franca Csoport.

Sani, A. M., \& Zain, Z. (2011). Relating Adolescents' Second Language Reading Attitudes, Self-Efficacy for Reading, and Reading Ability in a Non-Supportive ESL Setting. The Reading Matrix, Vol: 11, No. 3, pp. 243-255.

Schunk, D. H. (1985). Self-Efficacy and Classroom Learning. Psychology in the Schools, 22 (2), 208-223.

Shah, P. M., Mahmud, W. W., Din, R., Yusof, A., \& Pardi, K. M. (2011). Self Efficacy in the Writing of Malaysian ESL Learners . World Apllied Sciences Journal 15 (Innovation and Pedagogy for Lifelong Learning, 8-11.

Shumin, K. (2002). Factors to consider: Developing Adult EFL Students' Speaking Abilities . In J. C. Richards, \& W. A. Renandya, Methodology in Language Teaching: An Anthology of Current Practice (pp. 204-211). the United
States of America: Cambridge University Press.

Spratt, M., Pulverness, A., \& Williams, M. (2011). the Teaching Knowledge Test Course: Modules 1, 2 and 3. Singapore: Cambridge University Press.

Tilfarlioglu, F. T., \& Cinkara, E. (2009). Self-Efficacy in EFL: Differences among Proficiency Groups and Relationship with Success. Novitas Royal, Vol: 3(2), 129-142.

Wang, C. (2007). A First Grade Chinese Student's Self-Efficacy Belief about Learning English in American Classrooms and a Chinese Community. Multicultural Learning and Teaching, Vol: 2(2), 14-28.

Zeynali, S. (2012). Exploring the Gender Effect on EFL Learners' Learning Strategies. Theory and Practice in Language Studies, Vol. 2 No. 8 pp. 1614-1620.

Zimmerman, B. J. (2000). Self-Efficacy: An Essential Motive to learn. Contemporary educational Psychology, 25, 82-91. 